\title{
Industrial Upgrading Effect of OFDI of Sichuan Province of China
}

\author{
Xiaohui Wang ${ }^{1}$ \\ ${ }^{1}$ School of Economics and Management, LeShan Normal University, LeShan, China \\ Correspondence: Xiaohui Wang, School of Economics and Management, LeShan Normal University, No. 402, \\ Unit 2, JinLin, ManTingFang, No. 776, Xiaoba Road, LeShan City, Sichuan Province, China. E-mail: \\ scsnwxh@qq.com
}

Received: September 10, 2018

Accepted: September 21, 2018

Online Published: September 28, 2018

doi:10.5539/ijef.v10n10p138

URL: https://doi.org/10.5539/ijef.v10n10p138

\begin{abstract}
Despite the upgrading of industrial structure is not the direct purpose of OFDI, the experience of many countries shows that there is a connection between them. Through the method of fixed effect and SGMM, this paper aims to estimate and analysis the industrial upgrading effect of OFDI of Sichuan province of China, using the panel data of 31 districts of China from 2003 to 2016. From the empirical results we come to the conclusion that OFDI can promote the optimization and upgrading of industrial structure in China and in Sichuan province. For every $1 \%$ increase in OFDI, China's industrial structure index rose $0.00182 \%$ and Sichuan's industrial structure index rose $0.0237 \%$.
\end{abstract}

Keywords: industrial structure, optimization and upgrading, OFDI, fixed effect, SGMM

\section{Introduction}

Industrial structure refers to the composition and proportion of each industry in a economy and the relationship between each industry. Colin Clark(1960) revealed the law of the evolution of industrial structure as the change of per capita income leads to labor flow and the industrial transformation from primary industry to secondary industry and then to tertiary industry. The 16th national congress of the communist party of China (CPC) has made arrangements to optimize and upgrade the industrial structure in accordance with the new trend of world economic and technological development. The optimization and upgrading of industrial structure is the organic unification of industrial structure rationalization and industrial structure sophistication. Rationalization of industrial structure refers to the improvement of the quality of convergence between industries, which can be expressed by the degree of balance and the degree of correlation between industries. Industrial structure sophistication refers to the process of the development of industrial structure from primary industry to secondary and tertiary industries. The proportion of secondary and tertiary industries, technology and capital intensive industries and the proportion of intermediate and ultimate industries can be used to measure the level, stage and direction of a country's economic development. Compared with the U.S. industrial structure index of 2.793 in 2016, China's 2.45 and Sichuan's 2.353 are much lower. The industrial structure of China and Sichuan province needs optimizing and upgrading. All factors affecting economic growth have direct or indirect effects on changes in industrial structure in varying degrees. Knowledge and technology innovation, population scale and structure, economic system, natural resource endowment, capital scale, demand structure, international trade and international investment are important constraints in the evolution process of a country's industrial structure.

As one important way of global operation, outward foreign direct investment (Hereinafter, OFDI) can affect industrial structure through obtaining overseas resources, absorbing advanced technologies and transferring marginal industries. According to statistical data from department of outward investment and economic cooperation of ministry of Commerce of the People's Republic of China, in 2017, Chinese domestic investors made non-financial direct investment to 6236 overseas enterprises in 174 countries and regions, with a total investment of 120.08 billion USD. Which is 42 times the 2.85 billion USD invested in 2003. During the same period, Sichuan's OFDI grows by 960 times, from 1.47 million USD to 1412.01 million USD. The fast growth of OFDI has changed China's allocation of resources and brought advanced technology and strategic assets. But the effect of upgrading industrial structure is still need to be verified.

This paper aims to estimate and analysis the industrial upgrading effect of OFDI of Sichuan province of China through the method of fixed effect and SGMM, using the panel data of 31 districts of China from 2003 to 2016. 
This paper also table a proposal of the optimization of OFDI and industrial structure.

\section{Literature Review}

Scholars outside China began to theoretically study the relationship between OFDI and the upgrading of the domestic industrial structure very early. In 1932, Kaname Akamatsu, a Japanese economist, put forth the flying geese pattern of economic development in his paper The comprehensive principle of Japan's economic development. The flying geese pattern suggests that developing countries can realize industrialization, heavy industrialization and high processing degree through the circulation of foreign introduction, domestic production and product export and then upgrade industrial structure. Another Japanese economist, Kojima Tojima, bring forward marginal industry expansion theory by applying the principle of comparative advantage in international trade to international direct investment in 1978. He believe that foreign investment in the order of 'marginal industries' can upgrade domestic industrial structure by international transfer of industries because that the transfer of marginal industries can save resources for comparative advantage industries and emerging industries. The theory of technological innovation and industrial upgrading proposed by Cantewell and Tolentino in 1990 believed that the gradually upgrade of OFDI from resource-oriented to technology-oriented and market-oriented can upgrade the industrial structure of home countries through promoting the technological accumulation of developing investment countries and improving the technological capacity of enterprises.

From the perspective of empirical research, many researchers found that OFDI played a positive role in industrial structure upgrading. Through studying Japan's OFDI from 1970s to 1990s, Hiley (1999) found that Japan transfer production resources from disadvantaged industries to advantageous industries by transferring its textile and machinery industries, which were at a comparative disadvantage, to ASEAN countries. Blomstrom (1999) verified that Japan's OFDI in the second half of the 20th century effectively promoted the change of domestic economic structure and the adjustment of industrial structure through his empirical research. Through empirical research on Korean's OFDI, Advincula (2000) found that Korean's OFDI helps enterprises to transfer from low value-added link to high value-added link, which can promote the optimization of enterprise production structure and upgrading of related industries. Lipsey (2002) found that OFDI can promote the upgrading of industrial structure of home country through transferring its production factors to emerging industries. Giuliani, Pietrobelli, and Rabellotti (2005) analyzed the influence of OFDI on industrial structure upgrading from the perspective of value chain and concluded that the agglomeration effect of OFDI had a positive influence on industrial structure upgrading. Through researching typical cases of multinational companies, Mathews (2006) found that OFDI can promote the upgrading of industrial structure of home country by the ways of resource linkage, leverage effect and learning by doing.

The research of the upgrading effect of OFDI on industrial structure of home country is a relatively new field in China. Qi (2004) found that OFDI can promote industrial upgrading in the ways of resource filling, transferring of marginal industrial, promoting emerging industries and industrial association. Similar conclusions are found in the researches of Chunxiao (2009), Wei (2010), Fengchun (2012) and JianQing (2013). Sukun and Ran (2014) analyzed the mechanism of the upgrading effect of OFDI on industrial structure from the point of OFDI motive, they came to the conclusion that market-seeking OFDI can transfer marginal industries, resource-seeking OFDI can obtain important resource for the development of emerging industries, technology-seeking OFDI can obtain advanced technology for major industries, and then OFDI with different kinds of motive can all promote the upgrading of industry structure.

From the exiting researches, OFDI has a positive influence on the upgrading of industrial structure of home country. But the conclusion was all made by the researches of national level, few scholar researches this issue in district level. So, this paper aims to estimate and analysis the industrial upgrading effect of OFDI of Sichuan province of China through the method of fixed effect and SGMM, using the panel data of 31 districts of China from 2003 to 2016.

\section{Research Design}

\subsection{Theoretical Analysis}

OFDI can be classified into market seeking, resource seeking, technology seeking and efficiency seeking according to its motivation. Each kind of OFDI has its special investment domain and distinguishing feature. So we analyze the mechanism of upgrading effect of OFDI on industrial structure from these four motivations.

The main purpose of market-seeking OFDI is to expand existing markets and explore new markets. The home country of investment transfers its comparatively advantage industry which is in the late stage of product life to the host country. This kind of OFDI can release the production factors from traditional industries to emerging 
industries, and then provide necessary foundation of material and technological for the upgrading of industrial structure. On the other hand, it can also lengthens the life cycle of the traditional industry and reduces the adverse impact on domestic economic caused by industrial restructuring. So market-seeking OFDI can promote the upgrading of industrial structure of home country.

Resource-seeking OFDI's aim is to obtain the best production resources abroad. This kind of OFDI can increase the supply of scarce resources in home country by obtaining the relative scarce resources overseas. Thus, the contradiction between development and the scarcity of resources in home country which is the bottleneck problem in the adjustment of industrial structure can be solved. Then the industrial structure of home country can be upgraded.

Technology-seeking OFDI means the subsidiary corporation is established to absorb advanced technology globally. Enterprises established through OFDI can get in touch with advanced production technology and management experience in developed countries and regions. Then, the subsidiary corporation can increase technical competence by learning or purchase. Parent company in home country can improve its technical level through reverse technology spillover. At last, high-end industries of home country can be reformed and upgraded. So, technology-seeking OFDI can promote the upgrading of industrial structure in home country.

Efficiency-seeking OFDI can help enterprises avoid tax barriers in global markets and reduce production costs. Enterprises can concentrate their capital on technology research and development. So, efficiency-seeking OFDI can not only explore international market, but also improve domestic technology level. Therefor, efficiency-seeking OFDI can promote the upgrading of industrial structure in home country.

\subsection{Model Specification}

Industrial upgrading is a gradual and dynamic process, it can be affected by investment, technology improvement, international trade, institutional arrangements and many other factors. In the process of industrial upgrading, technology improvement is the direct driving force, investment is the material foundation. Therefore, except for OFDI, this paper adds domestic investment and foreign direct investment to the research model of industrial structure upgrading as independent variables.

$$
\ln I S L_{i t}=\beta_{0}+\beta_{1} \ln O F D I_{i t}+\beta_{2} \ln K_{i t}+\beta_{3} \ln F D I_{i t}+\varepsilon_{i t}
$$

Where $I S L_{i t}$ represents industrial structure level of $i$ district of China in $t$ year, $O F D I_{i t}$ represents OFDI stock of $i$ district of China in $t$ year, $K_{i t}$ represents the amount of domestic investment of $i$ district of China in $t$ year, $F D I_{i t}$ represents the amount of absorbed inward foreign direct investment of $i$ district of China in $t$ year, $\varepsilon_{i t}$ represents the random disturbance term. The logarithmic model was adopted because that logarithmic model can make biased data close to normal distribution, solve the problem of heteroscedasticity and we can study the elastic relationship between independent variables and dependent variables.

There are many indicators to measure the industrial structure level, scholars choose different indicators according to different research purposes. This paper adopts the method of measuring industrial structure level used by Xueqing (2005) and Jun (2008). The formula for calculating the indicate of industrial structure level is as follows:

$$
I S L=3 q(1)+2 q(2)+q(3)
$$

In the calculate formula, $q(1)$ represents the proportion of the added value of the tertiary industry in GDP, $q(2)$ represents the proportion of the added value of the secondary industry in GDP, and $q(3)$ represents the proportion of the added value of the primary industry in GDP. The higher the ISL value, the higher the level of industrial structure and the higher the degree of industrial structure optimization. Conversely, the lower the ISL value, the lower the level of industrial structure and the lower the degree of industrial structure optimization.

\subsection{Data and Descriptive Statistics}

The data of GDP of 31 provinces of China and the added value of primary industry, secondary industry and tertiary industry of 31 provinces of China are from the statistic yearbook of National Bureau of Statistics of China. Then, the value of $I S L$ of 31 provinces from 2003 to 2016 can be calculated. The data of domestic investment and foreign direct investment of 31 provinces from 2003 to 2016 are also from the statistic yearbook of National Bureau of Statistics of China. The data of OFDI stock is from Statistical Bulletin of China's Outward Foreign Direct Investment of 2016. The descriptive statistics of all variables are as shown in table 1. 
Table 1. Variable descriptive statistics

\begin{tabular}{|c|c|c|c|c|c|c|}
\hline variable & & Mean & Std.Dev. & Min & Max & Observations \\
\hline \multirow{3}{*}{ logisl } & overall & .834199 & .0515351 & .7270556 & 1.028642 & $\mathrm{~N}=434$ \\
\hline & between & & .0484636 & .78014 & 1.006708 & $\mathrm{n}=31$ \\
\hline & within & & .0194336 & .7811146 & .8937041 & $\mathrm{~T}=14$ \\
\hline \multirow{3}{*}{ logofdi } & overall & 3.536099 & 2.444836 & -4.611953 & 9.024699 & $\mathrm{~N}=434$ \\
\hline & between & & 1.702151 & -1.058114 & 6.76526 & $n=31$ \\
\hline & within & & 1.779576 & -2.282933 & 7.568861 & $\mathrm{~T}=14$ \\
\hline \multirow{3}{*}{$\log k$} & overall & 8.473067 & 1.186369 & 4.897542 & 10.83778 & $\mathrm{~N}=434$ \\
\hline & between & & .8520338 & 6.072796 & 9.813546 & $\mathrm{n}=31$ \\
\hline & within & & .8386335 & 6.745128 & 9.981843 & $\mathrm{~T}=14$ \\
\hline \multirow{3}{*}{$\operatorname{logfdi}$} & overall & 5.278167 & 1.728041 & -2.302585 & 8.452655 & $\mathrm{~N}=434$ \\
\hline & between & & 1.610234 & .0845273 & 7.808511 & $\mathrm{n}=31$ \\
\hline & within & & .6863798 & 2.891054 & 8.812096 & $\mathrm{~T}=14$ \\
\hline
\end{tabular}

In order to find out the relationship between China's industrial structure level and OFDI, this paper draw a scatter plot of logarithm of the index of China's industrial level and logarithm of OFDI. According to figure 1, we find out that there is a positive relationship between China's industrial level and OFDI. But, this kind of relationship needs to be verified by empirical study.

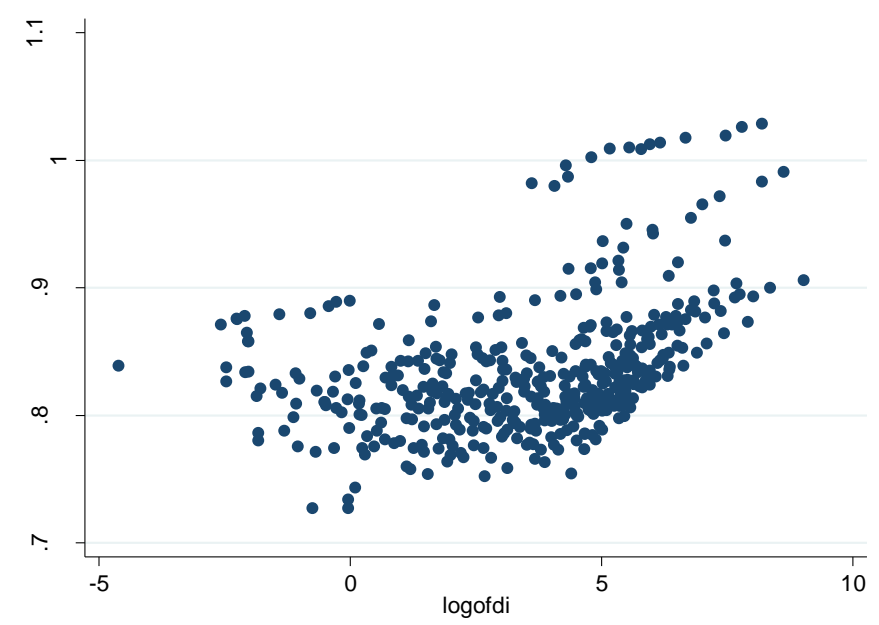

Figure 1. Scatter plot of China's industrial structure level and OFDI

\section{Empirical Analysis}

\subsection{Research Method}

Panel data usually provides researchers with a large number of data points, so it increases the degree of freedom of the data and reduces the degree of collinearity between explanatory variables, thus it can improve the accuracy of the econometric model estimation. So, panel data model is employed in this paper's estimation which is made by STATA soft.

Before estimation, this paper made stationary test of panel data. Then, this paper estimated the panel data model by the method of pool regression, random effect regression and fixed effect regression and made Hausman test to find out the most suitable method of the estimation. Furthermore, this paper estimated the panel data model with SGMM because of the allowance of heteroscedasticity and serial correlation in the random error. At last, in order to find out the upgrading effect of industrial structure of Sichuan province, this paper estimates the panel data model with region dummy variable added and estimates the time series data of Sichuan province with OLS.

\subsection{Stationary Test}

This paper made the test of stationary to avoid false regression. After the test of stationary with the method of LLC, Harris-Tzavalis and Breitung, we found that all variables are not stationary. Then, we made the stationary test on the difference of variables and found that the difference of variables are stationary. All the statistics and $\mathrm{P}$ values are shown in Table 2. 
Table 2. Results of stationary test of all variables

\begin{tabular}{clllllllll}
\hline \multicolumn{2}{c}{ variable } & logisl & logofdi & logk & logfdi & logisldif & logofdidif & logkdif & logfdidif \\
\hline \multirow{2}{*}{ LLC } & statistic & 6.3709 & -7.2534 & -9.2628 & -6.5682 & -2.4247 & -3.7048 & -1.0175 & -2.5640 \\
& P value & 1.0000 & 0.0000 & 0.0000 & 0.0000 & 0.0077 & 0.0001 & 0.1545 & 0.0052 \\
\multirow{2}{*}{ HT } & statistic & 1.0481 & 0.9030 & 0.9464 & 0.7328 & 0.1345 & -0.0321 & 0.6890 & -0.4149 \\
& P value & 1.0000 & 0.9974 & 1.0000 & 0.0339 & 0.0000 & 0.0000 & 0.0070 & 0.0000 \\
& statistic & 7.7886 & 10.8614 & 13.0744 & 6.0218 & -3.1858 & -4.5995 & -3.8409 & -3.7191 \\
\multirow{2}{*}{ Breitung } & P value & 1.0000 & 1.0000 & 1.0000 & 1.0000 & 0.0007 & 0.0000 & 0.0001 & 0.0001 \\
\hline
\end{tabular}

Since all variables are not stationary and all variables' differences are stationary, we did co-integration test to find out if there is a co-integration relationship between dependent variable and independent variables. The result of co-integration test shown as table 3 indicates that the co-integration relationship exits between dependent variable and independent variables basically. Besides, because the data in this study is short panel data with small $\mathrm{T}$ and large $\mathrm{N}$, the requirement of data co-integration is not strict. So, false regression can be avoided.

Table 3. Result of co-integration test

\begin{tabular}{lcccc}
\hline Statistic & Value & Z-value & P-value & Robust P-value \\
\hline $\mathrm{Gt}$ & 2.100 & 20.710 & 1.000 & 1.000 \\
$\mathrm{Ga}$ & -0.009 & 6.955 & 1.000 & 1.000 \\
$\mathrm{Pt}$ & -2.054 & 4.027 & 1.000 & 0.000 \\
$\mathrm{~Pa}$ & -0.043 & 3.726 & 1.000 & 0.000 \\
\hline
\end{tabular}

\subsection{Regression Analysis}

This paper estimated the model with random effect firstly. Breusch and Pagan Lagrangian multiplier test for random effects indicates that estimation with random effect is more suitable for the model than estimation with pool regression. The result of $\mathrm{F}$ test in regression 2 with fixed effect indicates that fixed effect is more suitable for the model than estimation with pool regression. Then, this paper made Hausman test to find out whether random effect or fixed effect are more suitable for the model and the result shows that fixed effect is more suitable. After that, regression 4 with the method of SGMM, regression 5 with OLS and region dummy variable, regression 6 with Sichuan province's time series data were made. The results of regression 1 to regression 6 are shown as in Table 4.

Table 4. Regression result

\begin{tabular}{|c|c|c|c|c|c|c|}
\hline $\begin{array}{l}\text { explaining } \\
\text { variables }\end{array}$ & $\begin{array}{c}\text { Regress1 logisl } \\
\text { RE }\end{array}$ & $\begin{array}{c}\text { Regress2 logisl } \\
\text { FE }\end{array}$ & $\begin{array}{c}\text { Regress3 logisl } \\
\text { FE+Robust }\end{array}$ & $\begin{array}{c}\text { Regress4 logisl } \\
\text { sysGMM }\end{array}$ & $\begin{array}{l}\text { Regress5 logisl } \\
\text { OLS+dummy }\end{array}$ & $\begin{array}{c}\text { Regress6 logisl } \\
\text { OLS(Sichuan) }\end{array}$ \\
\hline L.logisl & & & & $\begin{array}{l}0.968 * * * \\
(0.0164)\end{array}$ & & \\
\hline logofdi & $\begin{array}{l}0.00507 * * * \\
(0.00116)\end{array}$ & $\begin{array}{l}0.00435 \text { *** } \\
(0.00116)\end{array}$ & $\begin{array}{l}0.00435^{*} \\
(0.00251)\end{array}$ & $\begin{array}{l}0.00182 * * * \\
(0.000227)\end{array}$ & $\begin{array}{l}0.00435^{* * * *} \\
(0.00116)\end{array}$ & $\begin{array}{l}0.0237 * \\
(0.0121)\end{array}$ \\
\hline $\log \mathrm{k}$ & $\begin{array}{l}0.00928 * * * \\
(0.00258)\end{array}$ & $\begin{array}{l}0.0111 * * * \\
(0.00260)\end{array}$ & $\begin{array}{l}0.0111 * * \\
(0.00415)\end{array}$ & $\begin{array}{l}0.00113^{* *} \\
(0.000486)\end{array}$ & $\begin{array}{l}0.0111^{* * *} \\
(0.00260)\end{array}$ & $\begin{array}{l}0.0226 \\
(0.0176)\end{array}$ \\
\hline $\operatorname{logfdi}$ & $\begin{array}{l}-0.00473^{* * *} \\
(0.00181)\end{array}$ & $\begin{array}{l}-0.00513 * * * \\
(0.00186)\end{array}$ & $\begin{array}{l}-0.00513 \\
(0.00383)\end{array}$ & $\begin{array}{l}0.000342 \\
(0.000432)\end{array}$ & $\begin{array}{l}-0.00513^{* * *} \\
(0.00186)\end{array}$ & $\begin{array}{l}-0.0542 * * * \\
(0.0132)\end{array}$ \\
\hline Constant & $\begin{array}{l}0.763 * * * \\
(0.0184)\end{array}$ & $\begin{array}{l}0.752 * * * \\
(0.0169)\end{array}$ & $\begin{array}{l}0.752 * * * \\
(0.0331)\end{array}$ & $\begin{array}{l}0.0121 \\
(0.0107)\end{array}$ & $\begin{array}{l}0.812 * * * \\
(0.0172)\end{array}$ & $\begin{array}{l}0.822 * * * \\
(0.156)\end{array}$ \\
\hline Sichuan & & & & & $\begin{array}{l}-0.101 * * * \\
(0.00932)\end{array}$ & \\
\hline Observations & 434 & 434 & 434 & 403 & 434 & 14 \\
\hline R-squared & & 0.516 & 0.516 & & 0.931 & 0.845 \\
\hline Number of region & 31 & 31 & 31 & 31 & 31 & 1 \\
\hline
\end{tabular}

Robust standard errors in parentheses; *** $\mathrm{p}<0.01, * * \mathrm{p}<0.05, * \mathrm{p}<0.1$. 
From the result of regression 1 to regression 6 in table 4, we believe that the model in this paper is suitable for the research because that the goodness of fit of the model is high and most of coefficients are significant. The coefficients of logofdi in regression 1 to regression 6 are all positive, which means that China's OFDI can promote the upgrading of industrial structure. Because the $\mathrm{P}$ value of sargan test of overidentifying restrictions of regression 4 is 0.1386 , we can accept hypothesis 0 which is overidentifying restrictions are valid. The coefficients of logofdi, logk and logfdi in regression 4 are all positive, which means that OFDI, domestic investment and FDI can all promote the upgrading of industrial structure of China. So, regression 4 with the method of SGMM is more valid and close to practice. In regression 4, the amount of coefficient of logofdi comes to 0.00182 , which indicates that for every $1 \%$ increase in OFDI, China's industrial structure index rose $0.00182 \%$. In regression 5, the amount of coefficient of dummy variable of Sichuan province comes to -0.101 , which indicates that Sichuan province's upgrading effect of industrial structure is $10.1 \%$ lower than that of other provinces. In regression 6 with Sichuan province's time series data, the amount of coefficient of logofdi comes to 0.0237 , which means that for every $1 \%$ increase in OFDI, Sichuan province's industrial structure index rose $0.0237 \%$.

\section{Conclusion and Suggestion}

\subsection{Research Conclusion}

Through the method of fixed effect and SGMM, this paper estimates and analyzes the industrial upgrading effect of OFDI of Sichuan province of China, using the panel data of 31 districts of China from 2003 to 2016. after estimations, we believe that OFDI can promote the upgrading of industrial structure both in China and in Sichuan province. Market-seeking, resource-seeking, technology-seeking and efficiency-seeking OFDI can promote the upgrading of industrial structure in their own ways. This paper is a extension of research of industrial structure effect of OFDI. But this paper didn't analysis the specific reasons of industrial structure effect of OFDI empirically and it's moderating effect. Which are worth studying deeply for all scholars.

\subsection{Suggestion}

As discussed above, OFDI can promote the upgrading of industrial structure both in China and in Sichuan province. But, the upgrading effect in Sichuan province is lower than other provinces. The level of Sichuan's industrial structure is relatively low may be one important reason. So, Sichuan province needs to increase research and development investment and OFDI to upgrading technology of emerging industries.

\section{Acknowledgments}

A Project Supported by Scientific Research Fund of Sichuan Provincial Education Department (project number:17SB0169).

\section{References}

Advincula, V. (2000). Foreign direct investment, competitiveness and industrial upgrading: The case of the Republic of Korea. MA thesis, KDL.

Blomstrom, M., \& Sjöholm, F. (1999). Technology Transfer and Spillovers? Does Local Participation with Multinationals Matter? European Economic Review, 43(4-6), 915-923. https://doi.org/10.1016/S0014-2921(98)00104-4

Cantwell, J., \& Tolentino, P. (1990) Technological Accumulation and Third World Multinationals. Discussion Papers in International Investment and Business Studies, University of Reading, No. 139, May.

ChunXiao, F. (2009). An Empirical Study on China Outward Foreign Direct Investment and Industrial Structure's Optimization: Taking Manufacturing Industry as an Example. Journal of International Trade, (8), 97-104. DOI:10.13510/j.cnki.jit.2009.08.017

Clark, C. (1960). The Conditions Economic Progress. Population (French Edition), 15(2), 374-375. https://doi.org/10.2307/1525990

Fengchun, L. (2012). The Industrial Upgrading Effect of Home Countries' Outward Foreign Direct Investment: An Empirical Study from Provincial Panel of China. Journal of International Trade, (6), 124-134. DOI:10.13510/j.cnki.jit.2012.06.010

Giuliani, E., Pietrobelli, C., \& Rabellotti, R. (2004). Upgrading in global value chains: lessons from Latin American clusters. World Development, 33(4), 549-573. https://doi.org/10.1016/j.worlddev.2005.01.002

JianQing, Y. (2013). China's Outward Direct Investment on the Upgrading of Domestic Industries: An Empirical Analysis. Economic Geography, 33(4), 120-124. DOI:10.15957/j.cnki.jjdl.2013.04.002 
Jun, K. (2008). Relationship between industrial structure upgrading and economic growth. Statistics and Decision, (11), 83-84. DOI:10.13546/j.cnki.tjyjc.2008.11.029

Kojima, K. (1978). Direct Foreign Investment: A Japanese Model of Multinational Business Operations. New York: Praeger.

Lipsey, R. E. (2002). Home and Host Country Effects of FDI. NBER Working Paper, National Bureau of Economic Research. No. 9293. https://doi.org/10.3386/w9293

Mark, H. (1999). The dynamics of changing comparative advantage in the Asia-Pacific region. Journal of the Asia Pacific Economy, 4(3), 446-467. https://doi.org/10.1080/13547869908724693

Mathews, J. A. (2006). Dragon multinationals: new players in 21 st century globalization. Asia Pacific Journal of Management, 23(2), 139-141. https://doi.org/10.1007/s10490-006-7161-1

Qi, W. (2004). The effect of OFDI on industrial structure adjustment of home country and its transmission mechanism. Journal of International Trade, (5), 36-41. https://doi.org/10.13510/j.cnki.jit.2004.05.018

Sukun, P., \& Ran, Y. (2014). A theoretical and Empirical Study on the promotion of industrial upgrading by OFDI with different investment motives. Economist, (9), 69-76. https://doi.org/10.16158/j.cnki.51-1312/f.2014.09.020

Wei, Z. (2010). ODI and China's Industrial Upgrading: Mechanism Analysis and Empirical Checking. Journal of Zhejiang University (Humanities and Social Sciences), 40(3), 116-125. https://doi.org/10.3785/j.issn.1008-942X.2009.09.021

Xueqing, J. (2005). Industry Structure Upgrade And Economy Growth-The analysis of Yangtze Delta Area. Journal of Nantong Teachers' College (Social Science Edition), 21(3), 45-49.

\section{Copyrights}

Copyright for this article is retained by the author(s), with first publication rights granted to the journal.

This is an open-access article distributed under the terms and conditions of the Creative Commons Attribution license (http://creativecommons.org/licenses/by/4.0/). 